\title{
Ammonium metabolism and protection from urease mediated destruction in Helicobacter pylori infection
}

\author{
W D Neithercut, C Williams, M S Hossack, K E L McColl
}

\begin{abstract}
Aim: To investigate further the intracellular ammonium metabolism of Helicobacter pylori and the mechanism of its urease mediated destruction.

Methods: The mechanism of the in vitro destruction of $\boldsymbol{H}$ pylori was investigated by incubating it in buffer solutions, at pH 6.0, containing isocitrate or $a$ ketoglutarate in addition to urea concentrations which had previously been shown to destroy $H$ pylori.

Results: The median (range) 5 minute survival of $H$ pylori in $0.2 \mathrm{~mol} / \mathrm{l}$ citrate buffer (pH 6.0) in the absence of urea was $88 \%(18-184 \%)$ and was similar to its survival in $0.2 \mathrm{~mol} / 1$ isocitrate buffer in the absence of urea, median $88 \%$ (15-274\%). In the presence of $50 \mathrm{mmol} / 1$ urea the survival of $H$ pylori in the citrate buffer was reduced, $9.9 \%(0-146 \%)$, compared with its survival in isocitrate buffer with the same concentration of urea $37 \%$ $(0-274 \%)(p<0.01)$. A 72 hour preincubation of the organism with $10 \mathrm{mmol} / \mathrm{l} a$ ketoglutarate also increased the 5 minute survival of the organism in $0.2 \mathrm{~mol} / \mathrm{l}$ citrate buffer containing $50 \mathrm{mmol} / \mathrm{l}$ urea to $36 \%(9-145 \%)$ compared with its survival in the same buffer but without preincubation with $a$ ketoglutarate $0 \%(0-62 \%)$.

Conclusion: The protection of $H$ pylori from rapid destruction by the supply of compounds used in the intracellular metabolism of the ammonium shows that the urease mediated destruction of $H$ pylori can be explained by intracellular depletion of $a$ ketoglutarate as a result of over production of ammonium by uncontrolled urease activity.
\end{abstract}

(f Clin Pathol 1993;46:75-78)

Infection of the gastric antral mucosal surface by Helicobacter pylori occurs in almost all patients with duodenal ulcers. ${ }^{2}$ Eradication of the infection during treatment results in the prolonged healing of the ulcer; failure to eliminate the organism usually results in recurrence of the duodenal ulcer ${ }^{34}$ and suggests that infection of the antral mucosa by $H$ pylori may be one of the most important acquired factors in the development of duodenal ulcer disease.

This organism is also unusual in that it possesses abundant urease activity. ${ }^{56}$ It was originally suggested that the organism may use its urease activity to protect itself from low gastric juice $\mathrm{pH}$ by the production of an alkaline microenvironment, as in vitro studies have shown that it did not survive well below $\mathrm{pH} 4.0$ in the absence of urea. ${ }^{7}$ In a series of in vivo studies we have already shown that it is unlikely that the organism causes alkalinisation of the gastric antrum sufficient to alter plasma gastrin concentration. ${ }^{89}$ Previous in vitro studies have also shown that the organism's urease activity may be harnessed to cause its destruction in $0.2 \mathrm{~mol} / 1$ citrate buffer $(\mathrm{pH} 6.0) .^{1011}$ The speed of the organism's destruction, the loss from the incubation medium of ammonium produced by its urease activity, and the absence of toxicity to the organism by high extracellular concentrations of ammonium ions all suggested that the destruction of the organism was mediated through its intracellular metabolism of ammonium.

Urease activity is used to scavenge nitrogen from urea by many other micro-organisms. Assimilation of ammonia generated by urease activity is usually accomplished by the conversion of ammonium and $a$ ketoglutarate to glutamate by glutamate dehydrogenase, or by the conversion of ammonium and glutamate to glutamine by the enzyme glutamine synthetase (figure).

$H$ pylori is known to possess glutamate dehydrogenase activity. ${ }^{5}$ The destruction of the organism could therefore result from the intracellular depletion of $a$ ketoglutarate. This molecule links carbohydrate and fat metabolism with amino acid and purine metabolism. Its depletion could therefore result in the stoppage of essential metabolic pathways and also alter intracellular $\mathrm{pH}$ through the accumulation of excess ammonium ions.

To investigate whether the depletion of $a$ ketoglutarate was the key to the organism's destruction we conducted a series of in vitro studies to investigate the effects of the supply of $a$ ketoglutarate or its precursor, isocitrate, on the organism's survival, under conditions which have previously resulted in its rapid metabolic destruction.

\section{Methods}

The survival of $H$ pylori in $0.2 \mathrm{~mol} / 1$ isocitrate buffer $(\mathrm{pH} \mathrm{6.0)}$ in the presence or absence of $50 \mathrm{mmol} / \mathrm{l}$ urea was compared with its survival in $0.2 \mathrm{~mol} / 1$ citrate buffer at $\mathrm{pH} 6.0$ in four separate studies which produced 86 replicates. The production of ammonium and consumption of urea was also measured.

The effect of preincubating $H$ pylor $i$ with $a$ ketoglutarate was also investigated in a series of 


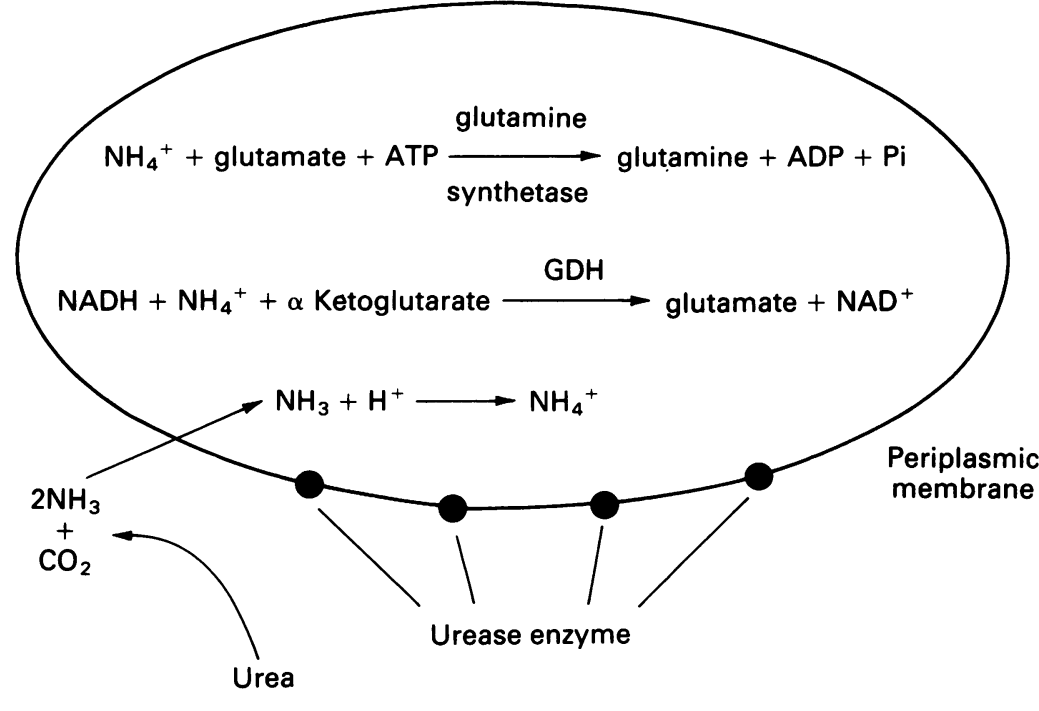

Possible methods of assimilation of urea nitrogen by Helicobacter pylori.
Pak Gas Generating System). The survival of the organism was expressed as a percentage of the starting inoculum calculated from the dilution of the viable colony count in the initial broth suspension. During isocitrate buffer studies, the $1 \mathrm{ml}$ samples collected for urea and ammonium analyses were filtered (Gelman Sciences, Acrodisc $0.2 \mu \mathrm{m}$ ) to remove the organism, snap frozen, and stored at $-20^{\circ} \mathrm{C}$ until analysis.

Stock $0.2 \mathrm{~mol} / 1$ citrate buffer ( $\mathrm{pH} 6.0$ ) was made by adding $100 \mathrm{ml}$ of $2 \mathrm{~mol} / \mathrm{l}$ citric acid to $280 \mathrm{ml}$ of $2 \mathrm{~mol} / 1 \mathrm{NaOH}$ and making the resultant solution up to 1 litre. Stock $0.2 \mathrm{~mol} /$ 1 isocitrate buffer ( $\mathrm{pH} 6 \cdot 0$ ) was made by dissolving $12.68 \mathrm{~g}$ of the trisodium salt of isocitric acid in $250 \mathrm{ml}$ of distilled water. The $\mathrm{pH}$ of the solution was then adjusted to 6.0 by the addition of $1 \mathrm{~mol} / 1 \mathrm{HCl}$. Buffers were equilibrated at $37^{\circ} \mathrm{C}$ and their $\mathrm{pH}$ checked before each experiment.

The Wilcoxon rank sum test for unpaired samples was used to compare differences between groups.

four complete studies which produced 24 replicates for analysis.

In each experiment $1 \mathrm{ml}$ of a 72 hour broth culture suspension (BHI broth $+0.25 \%$ yeast extract $+10 \%$ horse serum) of $H$ pylori was added to $9 \mathrm{ml}$ of $0.2 \mathrm{~mol} / 1$ buffer solution either containing urea or $\mathrm{NaCl}$ and incubated at $37^{\circ} \mathrm{C}$ for 5 minutes. At intervals portions were removed for viable bacterial counts and during the isocitrate buffer experiments for measurement of ammonium (Enzymatic method, Cobas Bio) and urea (o-pthalaldehyde method, Perspective analyser) concentration. ${ }^{8}$ The osmolality of the buffer solutions was checked using a (Advanced Digimatic Osmometer, Sussex, UK) osmometer. The following studies were undertaken:

1 Effect of isocitrate buffer on survival of $H$ pylori The survival of the organism in the presence of $50 \mathrm{mmol} / 1$ urea in $0.2 \mathrm{~mol} / 1$ isocitrate buffer $(\mathrm{pH} \mathrm{6.0)}$ was compared with its survival in $0.2 \mathrm{~mol} / \mathrm{l}$ citrate buffer with the same concentration of urea, and with its survival in $0.2 \mathrm{~mol} / 1$ citrate buffer, without urea but with added $\mathrm{NaCl}$ to ensure that the osmolality was the same as the citrate and isocitrate buffers containing urea. Urea consumption and ammonium release were also measured.

2 Effect of preincubation with a ketoglutarate on survival of $H$ pylori $H$ pylori was preincubated with $10 \mathrm{mmol} / \mathrm{l} a$ ketoglutarate which had been added to the broth for 15 minutes, 45 minutes or 72 hours before inoculation into $0.2 \mathrm{~mol} / \mathrm{l}$ citrate buffer ( $\mathrm{pH} 6.0)$. The effect of preincubation with $a$ ketoglutarate on the organisms's survival in $0.2 \mathrm{~mol} / \mathrm{l}$ citrate buffer was compared with its survival in $0.2 \mathrm{~mol} / 1$ citrate buffer containing $50 \mathrm{mmol} / \mathrm{l}$ urea.

The method of Miles and Misra ${ }^{12}$ was used to establish the organism's survival. Viable colony counts were obtained on blood agar plates after three days of incubation at $37^{\circ} \mathrm{C}$ in a microaerophilic atmosphere (BBL Campy-

\section{Results}

EFFECT OF ISOCITRATE BUFFER ON SURVIVAL OF H PYLORI

The survival of $H$ pylori in $0.2 \mathrm{~mol} / 1$ citrate buffer was again reduced when urea was present. The median 5 minute (range) survival of $H$ pylor $i$ in the citrate buffer in the absence of urea was $88 \%(18-184 \%)$ compared with $9.9 \%(0-146 \%)$ when $50 \mathrm{mmol} / \mathrm{l}$ urea was present in the buffer $(p<0.01)$. The median 5 minute survival in the $0.2 \mathrm{~mol} / 1$ isocitrate buffer was $88 \%$ (15-274\%), while in isocitrate buffer containing $50 \mathrm{mmol} / \mathrm{l}$ urea, the median 5 minute surival was $37 \%(0-274 \%)$. The 5 minute survival of $H$ pylori in the isocitrate buffer $37 \%(0-274 \%)$ was greater than its survival in $0.2 \mathrm{~mol} / \mathrm{l}$ citrate buffer also containing $50 \mathrm{mmol} / \mathrm{l}$ urea $9.9 \%$ (0-146\%) $(\mathrm{p}<0.01)$.

The osmolality of the isocitrate and citrate buffers was similar. The osmolality of the 0.2 $\mathrm{mol} / \mathrm{l}$ citrate buffer containing $50 \mathrm{mmol} / \mathrm{l}$ urea was $601 \mathrm{mmol} / \mathrm{kg}$ compared with $592 \mathrm{mmol} / \mathrm{kg}$ for the $0.2 \mathrm{~mol} / \mathrm{l}$ isocitrate buffer containing 50 $\mathrm{mmol} / \mathrm{l}$ urea.

In the citrate buffer with $50 \mathrm{mmol} / \mathrm{l}$ urea the median final 5 minute concentration of urea had fallen by $3.8 \mathrm{mmol} / \mathrm{l}(0-28 \mathrm{mmol} / \mathrm{l})$ due to urease activity, compared with $3.9 \mathrm{mmol} / 1$ (0-24 $\mathrm{mmol} / \mathrm{l})$ in isocitrate buffer when it initially contained $50 \mathrm{mmol} / 1$ urea $(p=0.9$; NS). Similarly, there was no difference in the final 5 minute concentration of ammonium produced in either the citrate or isocitrate buffers as a result of the organism's urease activity. The median 5 minute ammonium concentration in the citrate buffer with 50 $\mathrm{mmol} / \mathrm{l}$ urea was $4.24 \mathrm{mmol} / \mathrm{l}(2 \cdot 11-27 \cdot 1$ $\mathrm{mmol} / \mathrm{l}$ ) compared with $5.34 \mathrm{mmol} / \mathrm{l}$ $(1.83-27.6 \mathrm{mmol} / \mathrm{l})$ in the isocitrate buffer with $50 \mathrm{mmol} / 1(\mathrm{p}=0.5 ; \mathrm{NS})$. The median percentage recovery of ammonium in both buffers was therefore similar at $56 \%$ in citrate buffer and $68 \%$ in the isocitrate buffer. 
EFFECT CF PREINCUBATION WITH $a$ KETOGLUTARATE ON SURVIVAL OF H PYLORI

The 5 minute survival of $H$ pylori in $0.2 \mathrm{~mol} / 1$ citrate buffer ( $\mathrm{pH} 6 \cdot 0)$ containing $50 \mathrm{mmol} / 1$ urea was improved by a 72 hour preincubation with $10 \mathrm{mmol} / 1 a$ ketoglutarate in the culture medium. The median (range) 5 minute survival in the citrate buffer with urea but without an $a$ ketoglutarate preincubation was $0 \%$ $(0-62 \%)$. The 5 minute survival in $0.2 \mathrm{~mol} / 1$ citrate buffer with $50 \mathrm{mmol} / \mathrm{l}$ urea following a 72 hour preincubation with $a$ ketoglutarate was $36 \%(9-145 \%)(p<0.01)$. While survival in the citrate buffer with urea was improved by preincubation with $a$ ketoglutarate, it was still not as good as the organism's survival in the citrate buffer (pH 6.0) in the absence of urea, median 100\% (18-209\%).

A 15 and 45 minute preincubation with $a$ ketoglutarate before inoculation into $0.2 \mathrm{~mol} / 1$ citrate buffer ( $\mathrm{pH} 6.0)$ with $50 \mathrm{mmol} / 1$ urea did not improve the survival of the organism compared with its survival in the same buffer but without preincubation. The median (range) 5 minute survival of the organism in the citrate buffer with the urea following a 15 minute preincubation was $10 \%(0-40 \%)$ and with a 45 minute preincubation was $0 \%$ $(0-20 \%)$ compared with $0 \%(0-62 \%)$ without preincubation but in the presence of urea.

\section{Discussion}

These studies have again shown that the incubation of $H$ pylori in citrate buffer containing urea can result in the rapid destruction of the organism which did not occur in the absence of the urea. The rapid destruction of the organism over 5 minutes suggests that a catastrophic metabolic imbalance is produced as a result of the abundant and uncontrolled urease activity expressed by the organism. Changing the conditions of the 5 minute incubation with urea to provide the organism with additional supplies of the metabolites isocitrate and $a$ ketoglutarate required for the assimilation of ammonia resulted in an increase in the survival of the organism. These observations show that the organism's destruction was mediated through its inability to cope with the metabolic ammonia load under the conditions of the study.

In previous studies improved survival has also been shown when the $\mathrm{pH}$ of the incubate was increased to $7 \cdot 0 .{ }^{11}$ At that $\mathrm{pH}$ more ammonium was also released into the incubation medium. Together with the observations in this study this suggests that the death of the organism resulted from the accumulation of ammonium ions within the organism as a result of impaired excretion or from the exhaustion of the organism's stocks of $a$ ketoglutarate, required to incorporate ammonium into glutamate.

The $\mathrm{pK}_{\mathrm{a}}$ of the ammonia/ammonium equilibrium is $9 \cdot 13 .^{13}$ As a result virtually all ammonia in solution at $\mathrm{pH} 6.0$ will be present as ammonium ions. At $\mathrm{pH} 7 \cdot 4,98 \%$ of ammonia will be present as ammonium ions and in equilibrium with $2 \%$ as ammonia. In culture media at neutral $\mathrm{pH} H$ pylori deficient in urease activity leak ammonia produced by its deaminase activity due to the ease with which the unprotonated $2 \%$ can diffuse across the cell membrane; as a result the bacterium loses viability. ${ }^{14}$ If incubating the organism in $0.2 \mathrm{~mol} / \mathrm{l}$ buffer tends to alter the organism's cytosol $\mathrm{pH}$ towards that of the buffer then the difference in loss of ammonia produced by urease activity at buffer $\mathrm{pH} 6.0$ and 7.0 may be explained. At a buffer $\mathrm{pH} 7.0$ between $1-2 \%$ of intracellular ammonium will be present as ammonia which will diffuse across the cell membrane and become lost to the organism. At a lower intracellular $\mathrm{pH}$, which could be produced by incubation in buffer $\mathrm{pH} 6.0$, almost all of the intracellular ammonia would be present as ammonium ions. Little would therefore cross the cell membrane and escape from the organism. As a result the intracellular pathways of ammonium metabolism could become overloaded and lead to the destruction of the organism. At a pH of less than 5.0 the addition of urea to the incubation buffer paradoxically improved the survival of $H$ pylori. The amount of urea consumed by the organism was also reduced, suggesting impairment of the organism's urease activity due to the low $\mathrm{pH} .^{11}$ The smaller amounts of ammonium produced at lower $\mathrm{pH}$ would not be sufficient to overload intracellular metabolic processes but could help to maintain the bacterium's intracellular $\mathrm{pH}$.

The discrepancy between urea consumed and ammonium recovered in the incubate in our present and previous studies suggested that the urease enzyme is intracellular. However, electron microscopic visualisation of the urease enzyme has shown the localisation on the extracellular surface of the bacterium's periplasmic membrane. ${ }^{1516}$ Despite this, biochemical and electron microscopic observations can be reconciled. The uncontrolled urease activity of the organism could generate large quantities of ammonia from the hydrolysis of urea at sites on the periplasmic membrane. The local $\mathrm{pH}$ at these sites may be raised and thereby prolong the half-life of ammonia in its unprotonated form. This would permit diffusion of ammonia into the cell to allow the assimilation of the ammonia into the organism's metabolic processes. $H$ pylori is known to possess glutamate dehydrogenase activity which may be used for the incorporation of ammonia into amino acids. ${ }^{5}$ Urease activity is commonly used by bacteria to scavenge nitrogen from urea and this may therefore be the explanation for the high urease activity possessed by $H$ pylori.

Our previous studies have shown that citrate buffer ( $\mathrm{pH} 6.0)$ is required for the in vitro metabolic destruction of the organism. It has been suggested that the citrate may inhibit isocitrate dehydrogenase, a rate limiting enzyme which produces $a$ ketoglutarate from isocitrate. The isocitrate buffer was not as effective at protecting $H$ pylori from the destructive effects of its urease activity at $\mathrm{pH}$ 6.0 as citrate buffer was in causing its destruction. As isocitrate dehydrogenase is the rate 
limiting enzyme which controls the production of $a$ ketoglutarate from isocitrate the rate of production of $a$ ketoglutarate may have been slower than the production of intracellular ammonium by the organism's urease activity. The isocitrate used to make the buffer was, in addition, a racemic mixture. As only the $\mathrm{L}$ stereoisomer is biologically active then $H$ pylori was exposed to a lower biologically effective concentration of isocitrate compared with citrate. This could also explain the lower efficacy of the isocitrate buffer.

Preincubation of the organism with $a$ ketoglutarate for 72 hours improved the organism's survival in citrate buffer ( $\mathrm{pH} 6.0$ ) containing urea, while shorter preincubations over 15 or 45 minutes did not. If the rate of uptake of $a$ ketoglutarate by the organism was slow compared with its later production of ammonia by urease activity then this could explain this difference. Secondly, the organism may have been damaged by the disturbance of the microaerophilic culture atmosphere at 15 or 45 minutes prior to inoculation into the incubation medium.

In conclusion, these studies have shown that the organism's suicidal destruction in buffer ( $\mathrm{pH} 6 \cdot 0)$ in the presence of urea can be prevented by supplying metabolites required for intracellular ammonium metabolism. This indicates that the suicidal process is due to the intracellular accumulation of ammonium. It may be possible to harness the toxic effects of intracellular ammonium accumulation as a means of eradicating $H$ pylori infection in vivo.

We thank Mrs Jennifer Harwood for technical assistance.
1 Marshall BJ, McGechie DB, Rogers PA, Glancy RG. Pyloric campylobacter infection and gastroduodenal disease. Med $\mathcal{F}$ A ust 1985;142:439-44.

2 Axon AR. Duodenal ulcer: the villain unmasked. $B M F$ 1991;302:919-20.

3 Marshall BK, Goodwin CS, Warren JR, et al. Prospective double blind trial of duodenal ulcer relapse after eradication of Campylobacter pylori. Lancet 1988;ii:1437-42.

4 Rauws EAJ, Tytgat GNS. Eradication of Helicobacter pylori cures duodenal ulcer. Lancet 1990;i:1233-5.

5 Megraud F, Barnet F, Garner M, Lamouliatte $H$. Characterisation of Campylobacter pyloridis by culture enzymatic profile and protein content. $f$ Clin Microbiol enzymatic profile

6 Ferrero RL, Hazel SL, Lee A. The urease enzymes of Campylobacter pylori and a related bacterium. $\mathcal{F}$ Med Microbiol 1988;27:33-40.

7 Marshall BJ, Barrett LJ, Prakash C, McCallum RW, Guerrant RL. Urea protects Helicobacter (Campylobacter) pylori from the bacterial effects of acid. Gastroenterology 1990;99:697-702.

8 Chittajallu RS, Neithercut WD, MacDonald AMI, McColl KEL. The effect of increasing Helicobacter pylori ammonium production by urea infusion on plasma gastrin concentrations. Gut 1991;32:21-4.

9 Chittajallu RS, Neithercut WD, Ardill JES, McColl KEL. H pylori related hypergastrinaemia is not due to elevation of pylori related hypergastrinaemia is not due to elevation of
antral surface pH: studies with antral alkalinisation. Scand antral surface pH: studies with antrol

f Gastroenterol 1992;27:218-22.
10 Greig M, Neithercut WD, Hossack M, McColl KEL. Harnessing of urease activity of Helicobacter pylori to induce self-destruction of the bacterium. $\mathcal{F}$ Clin Pathol 1991;44:157-9.

11 Neithercut WD, Greig MA, Hossack M, McColl KEL. Suicidal destruction of Helicobacter pylori-a metabolic consequence of intracellular ammonium accumulation. $\mathcal{f}$ Clin Pathol 1991;44:380-4.

12 Miles AA, Misra SS. The estimation of the bactericidal power of the blood. $f$ Hygiene 1938;38:732-48.

13 Bramberg PA, Robin ED, Forkner CE. The existence of ammonia in the blood in vivo with observations on the significance of the $\mathrm{NH}_{4}{ }^{+}-\mathrm{NH}_{3}$ system. $\mathcal{f}$ Clin Invest 1960;39:332-41.

14 Catrenich CE, Makin KM. Characterisation of the morphologic conversion of Helicobacter pylori from bacillary to coccoid forms. Scand $\mathcal{F}$ Gastroenterol 1991;26(Suppl to coccoid form:

15 Bode G, Malfertheiner P, Nilius M, Ditschinert H. Ultrastructural localisation of urease in outer membrane and periplasm of Campylobacter pylori. $f$ Clin Pathol 1989;42:778-9.

16 Hawtin PR, Stacey AR, Newell DG. Investigation of the structure and localisation of the urease of Helicobacter pylori using monoclonal antibodies. F Gen Microbiol 